\title{
Juridical Analysis Regarding the Decision of the Central Supervisory Board against Violation Conducted by Notary (Case Study: Decision of the Notary Central Supervisory Board Number: Pts.04/B/MPPN/VII/2017)
}

\author{
Nuri Apriliani; Busyra Azheri; Delfiyanti \\ Faculty of Law, Universitas Andalas Padang, Indonesia
}

http://dx.doi.org/10.18415/ijmmu.v6i2.731

\begin{abstract}
The Notary Supervisory Board is the only institution authorized to conduct supervision and examination and impose sanctions on the notary. Another objective of the supervision is that the notary in carrying out his/her position can carry out the duties properly in accordance with the applicable laws and regulations, with the aim of serving the interests of the community appropriately. This thesis applies a normative juridical method and employs an empirical juridical approach. The data sources include primary, secondary and tertiary legal materials obtained through library study and information obtained by using interview guideline and field observation. Based on the research that had been conducted, it was found that the regulation regarding the imposition of sanctions for notaries who violated the laws and regulations has been regulated in Law No. 2 of 2014 concerning amendments to Law No. 30 of 2004 concerning Notary Position, Regulation of the Minister of Law and Human Rights of the Republic of Indonesia No. M.02.PR.08.10 of 2004 concerning Procedures for Appointment of Members, Dismissal of Members, Organizational Structure, and Procedures for Examination of Notary Supervisory Board, and Decree of the Minister of Law and Human Rights of the Republic of Indonesia No. M.39-PW.07.10 of 2004 concerning Guidelines for the Implementation of Tasks of the Notary Supervisory Board. Regarding the decision of the Supervisory Board, the reported notary has been given administrative sanctions in the form of written warnings and proposals for temporary dismissals. However, the reported notary made an appeal legal action. Then, regarding the violations committed by the notary, the Central Supervisory Board has issued a decision to reject the appeal from the Appellant/Reported Party which strengthens the Decision of the Notary Regional Supervisory Board of West Sumatra Province No. Pts.02/MPWN/SBR/2016.
\end{abstract}

Keywords: Juridical Analysis; Decision of the Supervisory Board; Violation; Notary

\section{Introduction}

Notary is a job that requires special expertise and requires extensive knowledge and big responsibility to serve the public interest. The essence of the notary's duty is to regulate in written and authentic form the legal relations between the parties who conscientiously request notary services. Regarding the importance of the role of notaries in people's lives, especially in making authentic deeds that are used as evidence, the notary has a position as a public official who has the authority to make 
authentic deeds and at the same time an extension of the government (Kuntjoro, 2016). The presence of a notary is desired by the rule of law with the intention of forming and serving the community which requires an authentic proof of the circumstances, events or legal actions; in this case, the notary must have the spirit to serve the community (Darus, 2017).

The form of legal services provided by a notary to the parties appearing to him/her is a request to make an authentic deed as written evidence that has perfect proof power. It is made in accordance with the provisions stipulated in the provisions of Law No. 2 of 2014 concerning Amendments to Law No 30 of 2004 concerning Notary Position. Furthermore, in Law on Notary Position it is referred to as an original deed. Original deed is a deed that includes the signatures of the appearers, witnesses, and notaries that are stored as part of the notary protocol, which is regulated in Article 1 paragraph 8. In addition, for parties in the deed, the notary provides a copy of the deed; i.e. word for word from all deeds which at the bottom of the copy of the deed include the phrase "given as a copy that sounds the same" as provided for in Article 1 paragraph 9 Law on Notary Position. Therefore, the notary is obliged to provide a copy of the deed to the parties after making a deed in accordance with Article 16 paragraph 1 letter $\mathrm{d}$ and Article 54 (Law on Notary Position) which reads:

"In carrying out his/her position, the notary is obliged to issue a grosse, copy, or duplicate of the deed based on the original deed and provide, show or notify the contents of the deed, grosse, copy or duplicate of the deed to interested persons directly on the deed, heir, or person who obtain rights, unless stipulated by the laws and regulations otherwise."

Notary, in carrying out his/her duties and positions, is supervised institutionally by 3 (three) institutions based on Law on Notary Position through the Notary Supervisory Board, Notary Honorary Assembly, and Notary Honorary Board (Ristiani, 2010). The three institutions have different authorities as stated in the legal rules that govern them (Adjie, 2017).

In order to supervise and foster the notary so that the implementation of his/her position does not harm the people who need their services, the Notary Supervisory Board is then established.

Based on Article 67 of Law No. 2 of 2014 concerning Notary Position:

(1) Supervision of notary is carried out by the minister;

(2) In carrying out the supervision referred to in paragraph 1, the minister forms a supervisory board;

(3) The supervisory board as referred to in paragraph 2 is 9 (nine), consisting of elements: a) the government of 3 (three) people; b) organization of 3 (three) people; and c) experts/academics 3 (three) people (Ruslan, 2013).

The formation of the Supervisory Board is intended so that the notary runs his/her position in accordance with the applicable laws and regulations, with the aim of serving the interests of the community well.

Society or party who feels disadvantaged by a notary in carrying out his/her position; for instance, there is a notary who does not read the deed to the appearer or does not provide a copy of the deed to the party on the deed, heir, proxy, or according to laws and regulations, for this matter the public can report it to the Notary Supervisory Board. The Notary Supervisory Board is the only agency authorized to supervise, examine and impose sanctions on the notary. Every report from the public regarding the violation of position carried out by a notary is first reported in writing to the Regional Supervisory Board which is domiciled in the city/regency. Meanwhile, for the process of sanctioning such violations, it will be carried out by the Regional Supervisory Board domiciled in the Provincial Capital which has the authority to provide sanctions in the form of verbal reprimand and final written warning. Meanwhile, giving sanctions for temporary dismissal and disrespectful dismissal or respectful dismissal, the Regional Supervisory Board provides recommendations to the Central Supervisory Board for these violations, which are authorized to examine and provide administrative sanctions for temporary dismissal, dismissal with disrespect and dismissal with respect to minister. 
The decree of the Minister which stipulates that the Central Supervisory Board has the authority to implement Article 84 Law on Notary Position has deviated from the essence of a civil sanction. Decree of the Minister of Law and Human Rights No. M.39-PW.07.10 of 2004 which is not necessary to be carried out. Basically, not all Central Supervisory Boards have the authority to impose sanctions, among others:

a. The Regional Supervisory Board does not have the authority to impose any sanctions. Even though the Regional Supervisory Board has the authority to receive reports from the public and from other notaries and hold a hearing to check for alleged violations of the implementation of the notary's office, they are not authorized to impose any sanctions. In this case, the Regional Supervisory Board is only authorized to report the results of the trial and its examination to the Regional Supervisory Board by making copies to the reporting party, the notary concerned, the Central Supervisory Board, and the notary organization;

b. The Regional Supervisory Board can impose sanctions in the form of verbal or written warnings. The Regional Supervisory Board can only impose sanctions in the form of verbal or written reprimand sanctions and this kind of sanctions is final.

c. The Central Supervisory Board can impose limited sanctions. The provisions of Article 77 letter c Law on Notary Position determine that the Central Supervisory Board has the authority to impose a temporary suspension. This kind of sanctions is a period of waiting for a certain period of time before other sanctions are imposed, such as sanctions for disrespectful dismissal from notary positions or respectful dismissals from notary positions.

Regarding other sanctions, the Central Supervisory Board is only authorized to propose:

1) Imposition of sanctions in the form of disrespectful dismissal from his/her position to the minister (Article 77 letter d Law on Notary Position);

2) Imposition of sanctions in the form of disrespectful dismissal from his/her position for certain reasons (Article 12 Law on Notary Position) (Adjie, 2017).

In carrying out his/her position, to carry out a legal action requested by him/her in the form of a notarial deed, after the original deed is signed by the parties, the notary is obliged to provide a copy of the deed to the parties concerned in the deed. In fact, there is a notary who does not provide a copy of the deed to the parties requesting the copy, then the parties reported the notary concerned to the Notary Supervisory Board, in this case the Regional Supervisory Board of Bukittinggi City who then conducted the examination.

The Regional Supervisory Board conducted an examination process on reports to the reported party who were proven not to provide copies to the reporting party. As a result, it had caused a violation of position against the provisions of Article 16 paragraph 1 letter d and Article 54 Law on Notary Position. Then, for the violation, based on the investigation report No. W3.HM.07.03.MPD.BKT-01 of 2016, the Regional Supervisory Board has conducted an examination of the notary reported by the party on the deed; i.e. deed number 63 dated 26 (twenty-six) in May of 2006 (two thousand and six). Then, the Regional Supervisory Board continued the process by submitting the examination report to the Regional Supervisory Board of West Sumatra Province as an institution that has the authority to provide administrative sanctions to the notary who did not provide a copy of the deed.

Based on the examination mechanism stipulated in the Regulation of the Minister of Law and Human Rights of the Republic of Indonesia and based on the authority to examine and judge itself every violation committed by a notary public, the Regional Supervisory Board through the Regional Audit Board checks the report of the case from the Regional Supervisory Board. The result was that the notary who was reportedly proven to have committed a violation of position.

Based on the authority possessed by the Regional Supervisory Board as stated in Article 73 of Law on Notary Position letter (e), the Regional Supervisory Board has the authority to impose sanctions in the form of verbal and written warnings. For violations committed by the reported notary, the Regional 
Supervisory Board is authorized to provide sanctions in the form of a written warning so that the notary submits a copy of the deed requested to the appearer. However, the reported notary still did not carry out the decision of the Regional Supervisory Board. Then, the reported notary felt dissatisfied with the decision of the Regional Supervisory Board and then submitted an appeal to the Notary Central Supervisory Board. Then, the Notary Central Supervisory Board processes it. Meanwhile, Article 73 paragraph (2) states that "the decision of the Regional Supervisory Board is final towards the provision of oral and written sanctions". This is also corroborated by the Regulation of the Minister of Law and Human Rights of the Republic of Indonesia Number: M.39.PW.07.10 of 2004 concerning the Guidelines for Implementing the Task of the Notary Supervisory Board which stated that the Central Supervisory Board is authorized to hold hearings to examine and make decisions in the appeal against imposition of sanctions except sanctions in the form of oral or written reprimand (Decree of the Minister of Law and Human Rights of the Republic of Indonesia Number: M.39.PW.07.10 of 2004 concerning Guidelines for the Implementation of Tasks of the Notary Supervisory Board).

Based on the description of the background above, some of the problems that will be discussed can be formulated, which include: (1) How is the arrangement of imposing sanctions on a notary who violates laws and regulations? (2) What are the legal consequences for the notary toward the decision of the Supervisory Board? (3) How is the implementation of the decision of the Central Supervisory Board regarding the violations committed by the notary in the case of the decision of the Regional Notary Supervisory Board of West Sumatra No. Pts.02/MPWA/SBR/2016?

\section{Research Method}

The method used in this research is a normative juridical method (Webley, 2010). Normative juridical legal research is a research on the principles of law or legislation, decisions, and also doctrines related to the problem under research (Soekanto, 1986). To support this research, an empirical juridical approach was also carried out; i.e. a legal research method that serves to see the law in the real sense and examine how the law works in the community (Buchanan et al., 2014).

\section{Results And Discussion}

\section{Arrangement of Imposition of Sanctions for Notary Who Violates Legislation}

In carrying out the position, in addition to referring to Law on Notary Position, the notary must also behave in accordance with the ethics of his/her profession. Professional ethics is an ethical attitude that must be fulfilled by professionals in carrying out their profession in which professional ethics vary according to their field of expertise (Yuniati, 2017).

To protect the interests of the general public and ensure the implementation of the Notary Position entrusted by the Law and the community, the existence of a legal arrangement regarding supervision of the implementation of the Notary Position is very appropriate. The purpose of the code of ethics is to prevent unethical behavior and provide direction and guarantee the moral quality of its members. The profession holders are required to prioritize their profession liability (Kanter, 2001). The Notary Supervisory Board has the authority to impose sanctions on the notary. This sanction is stated or regulated in Law on Notary Position, also mentioned again and added to in the Decree of the Minister of Law and Human Rights of the Republic of Indonesia No. M.39-PW.07.10 of 2004 concerning Guidelines for the Implementation of Duties of the Notary Supervisory Board. With such arrangements, there are sanctions arrangements that are not mentioned in the Law on Notary Position, but are regulated or mentioned also in the Decree of the Minister of Law and Human Rights of the Republic of Indonesia No. M. 39-PW.07.10 of 2004.

The mechanism carried out by the Regional Supervisory Board in the context of public reports of alleged violations of the notary code of ethics or violations of the implementation of notary positions is as follows: for the purposes of examination in connection with the receipt of public reports, the Chairperson of the Regional Supervisory Board forms an Audit Board from each element consisting of a chairperson 
and two members assisted by a secretary within a maximum of five working days from the receipt of the Notary Central Supervisory Board's report, through the Central Audit Board that will conduct the examination. It led to the absence of the reported party from the appropriate summon and twice in written and oral summons. In this case, the reported party did not heed or did not fulfill the summon. Therefore, the Audit Board can conduct an examination and make a decision stating that the report is declared null and cannot be submitted again, and the appeal has been cancelled. Thus, the reported notary will lose the right to defend him/herself.

The examination is carried out no later than seven calendar days after the report is received. In the first session where the reported party and the reporting party were present, the Audit Board began to conduct an audit by reading the report and statement of the reporting party, the Audit Board provided sufficient opportunity for the reported party to defend themselves. The reporting party or the reported party can submit evidence of the submitted argument. Then, the Audit Board makes the report of the examination signed by the chairman and secretary as much as two copies, of which one is to be submitted to the Regional Supervisory Board (Sjaifurrachman, 2011). The Law on Notary Position has arranged for sanctions for the notary. Therefore, basically not all Supervisory Boards have the authority to impose sanctions as explained below:

a. The Regional Supervisory Board does not have the authority to impose any sanctions. Even though the Regional Supervisory Board has the authority to receive reports from the public and from other notaries and conduct hearings to examine suspected violations of the Notary Code of Ethics or violations of the implementation of Notary Position, they are not authorized to impose any sanctions. In this case, the Regional Supervisory Board is only authorized to report the results of its trial and examination to the Regional Supervisory Board with a copy to the party reporting the notary concerned, the Central Supervisory Board, and the Notary Organization (Article 71 letter e Law on Notary Position).

b. The Regional Supervisory Board can impose sanctions in the form of oral or written warnings. The Regional Supervisory Board can only impose sanctions in the form of oral or written reprimand sanctions in which such sanctions are final and propose sanctions against the notary to the Central Supervisory Board in the form of temporary termination of notary positions for 3 (three) months to 6 (six) months or disrespectful dismissal from the Notary Position. Sanctions from the Regional Supervisory Board in the form of final verbal and written warnings cannot be categorized as sanctions but constitute the initial stage of the aspect of real coercive procedures which then the notary is subject to other sanctions such as a temporary termination of his/her position.

c. The Central Supervisory Board can impose limited sanctions. Article 77 letter c Law on Notary Position determines that the Central Supervisory Board has the authority to impose temporary dismissal. Such sanctions are a period of waiting for a certain period of time before other sanctions; for instance, a disrespectful dismissal from a Notary Position or a respectful dismissal from a Notary Position. Regarding other sanctions, the Central Supervisory Board is only authorized to propose: a) Imposing sanctions in the form of dishonorable dismissal from his/her position to the Minister (Article 77 letter d Law on Notary Position) and b) Imposing sanctions in the form of dishonorable dismissal from his/her position with certain reasons (Article 12 Law on Notary Position).

Based on the above explanation, sanctions in the form of verbal and written warnings can only be imposed by the Regional Supervisory Board. Sanctions in the form of a temporary dismissal from a Notary Position can only be made by the Central Supervisory Board, and sanctions in the form of disrespectful dismissal from a Notary Position and the honorable termination of a Notary Position can only be made by the Minister on the proposal of the Central Supervisory Board. Basically, the appointment and dismissal of a notary from his/her position in accordance with the rules of law, the appointment and dismissal must be carried out by the same agency, i.e. the Minister (Adjie, 2017). 


\section{Legal Consequences for Notary toward the Decision of the Supervisory Board}

As a public official (openbaar ambtenaar), the notary is authorized to make authentic deeds. In connection with this authority, the notary may be liable for his/her work in making an authentic deed. The liability of the notary as a public official includes the notary's own professional liabilities relating to the deed. In connection with this authority, the notary may be liable for his/her actions/work in making authentic deeds. The liability of the notary as a public official includes the notary's own professional liability relating to the deed, including: First is the civil liability of the notary for the deed he/she made. The liability in this case is the liability for the material truth of the deed, in the construction of illegal acts. Illegal actions here are actions that are both active and passive. Active means doing an act that causes harm to the other party. Whereas passive means not doing an act that is a necessity, so that the other party experiences a loss. So, the element of illegal action here is the existence of an unlawful act, an error, and the loss caused. Second is the liability of the criminal notary for the deed he/she made. Criminal matter in this case is a criminal act committed by a notary in his/her capacity as a general official authorized to make a deed; not in the context of individuals as citizens in general. Third is the administrative liability of the notary for the deed he/she made. Administrative sanctions based on Law No. 2 of 2014 states that there are 5 (five) types of administrative sanctions given if a notary public violates the provisions of Law No. 2 of 2014 that include: a. verbal warnings; b. written warning; c. temporary dismissal; d. respectful dismissal; and e. disrespectful dismissal (Afifah, 2017).

The role and authority of a notary are important for community's lives; so that the behavior and actions of the notary in carrying out his/her professional position are vulnerable to abuse which can harm the community. So, there needs to be an institution that functions to conduct guidance and supervision of the notary. The Supervisory Board is a body that has the authority and obligation to carry out guidance and supervision of the notary. Supervision of the notary is intended so that the notary in carrying out his/her job duties must be based on and follow the laws and regulations governing the position of a notary. This goal is to prevent the occurrence of violations that harm society (Endang Purwaningsih, 2015).

Guidance and supervision are important things that must be carried out by the Regional Supervisory Board. The Regional Supervisory Board has an important role for notaries within the region because the Regional Supervisory Board has the scope of authority to hold hearings to check for alleged violations of the Notary Code of Ethics, violations of notary positions and behavior of notaries outside their position which can interfere with or affect the implementation of the notary's job duties. Based on the case that the author examined, after not giving a copy of the deed, the notary was finally reported to the Regional Supervisory Board of the City of Bukittinggi. Then, the Regional Supervisory Board follows up on the report from the reporting party by calling the reported notary based on the Letter of Summon No. W3.HM.07.01.MPD.KTKT-02 of 2016 to be present at the examination where the schedule has been determined. In connection with the statement of the reporting party, the Regional Audit Board clarified the reported notary and found violations of Law No. 30 of 2004 concerning Notary Position as amended into Law No. 2 of 2014 concerning Notary Position. The results are based on the deliberation of the examination session of the Notary Regional Audit Board of Bukittinggi which was decided on June 8, 2016 and stated in the Report of Examination of the Regional Supervisory Board.

Due to position violations committed by the reported notary, the Regional Supervisory Board of Bukittinggi submitted the Report of Examination and recommendations of the Regional Supervisory Board of Bukittinggi to the Chairperson of the Notary Regional Supervisory Board of West Sumatra Province with letter No. W3.HM.07.01.MPD.BKT-03 of 2016 dated June 20, 2016, to follow up the examination of position violations committed by the reported party. The examination process was carried out first by selecting the chairman of the court. The chairperson of the hearing presided over the session by stating that the hearing was closed to the public. Furthermore, it was carried out by reading the report of examination of the Regional Examination Board and continued by giving the participants the opportunity to give their opinions. Through the implementation of the trial, after sufficient reasons had been obtained, the chairman of the hearing read out the verdict in the trial which was open to the public in which the verdict must be stated within a period of no later than 30 (thirty) calendar days after the file was received. The Regional Audit Board has performed its duties properly and in accordance with the 
stipulated period. Finally, the Regional Audit Board gave a ruling stating that the complainant's complaint could be accepted and punishing the reported notary by giving a sanction to the notary being examined in the form of a written warning as follows:

a. Order the reported notary to provide a copy of the deed regarding the agreement to replace the rights as reported by the reporting party within a period of no later than 15 (fifteen) days after this decision was received and included in the submission report of a copy of the deed which was then submitted to the Notary Regional Supervisory Board of West Sumatra Province.

b. Since the order - as referred to in number 1 -is not implemented, the reported notary will be proposed a temporary dismissal of 3 (three) months to the Notary Central Supervisory Board.

It was the decision obtained to be a deliberation meeting of the Notary Regional Audit Board of West Sumatra Province on Tuesday, July 19, 2016 consisting of chairman and members. This decision was pronounced in a session open to the public on Thursday, July 21, 2016, by the Audit Board assisted by the Secretary of the Board (Decision of the Regional Supervisory Board No. Pts.02/MPWA/SBR/2016).

The nature of sanctions is intended for a compulsion based on law and also to provide awareness to those who violate it, that an action that they have done is not in accordance with the applicable legal rules, to return the concerned person to act in accordance with the applicable law, and also to protect the balance of the rule of law. Sanctions aimed at notary are also an awareness that the notary, in carrying out his/her job duties, has violated the provisions regarding the implementation of notary position duties as stated in the Law on Notary Position. It is aimed also to guide notary actions in carrying out his/her duties according to Law on Notary Position.

\section{Implementation of the Decision of the Central Supervisory Board Regarding Violations Committed by a Notary}

The Regional Supervisory Board has issued a decision on violations committed by the reported notary; i.e. giving a sentence in the form of a written warning. With the recommendation of giving sanctions in the form of a temporary dismissal delivered by the Regional Audit Board, the reported notary can file an appeal. Appeals on the decision of the Regional Audit Board must be submitted in writing to the Notary Central Supervisory Board by being examined through the Regional Supervisory Board which will later send the appeal to the Notary Central Supervisory Board. As stipulated in Article 75 letter b of the Law on Notary Position and based on the Regulation of the Minister of Law and Human Rights of the Republic of Indonesia No. M.02.PR.08.10 of 2004 (Regulation of the Minister of Law and Human Rights 02/2004) Article 33, the reporting party or the reported party who feels an objection to the decision of the Regional Audit Board has the right to submit an appeal to the Notary Central Supervisory Board within a period of no later than 7 (seven) calendar days from the decision. If the reporting party or the reported party is not present at the time the decision is pronounced, the reporting party or the reported party can declare an appeal within a period of no later than 7 (seven) calendar days from the date the decision is received. The appellant must submit an appeal memory within a period of no later than 14 (fourteen) calendar days from the stated appeal (Regulation of the Minister of Law and Human Rights of the Republic of Indonesia No. M.02.PR.08.10 of 2004 concerning Procedures for Appointment of Members, Organizational Structure, Work Procedure and Procedure for Examination of the Notary Supervisory Board).

Based on the results of research at the Regional Office of the Ministry of Law and Human Rights of West Sumatra Province, the appeal memory of the reported notary has been submitted by the Regional Supervisory Board to the Central Supervisory Board. After reading and paying close attention to the provisions of Article 77 of Law No. 2 of 2014 concerning Amendments to Law No. 30 of 2004 concerning Notary Position jo. Article 29 Regulation of the Minister of Law and Human Rights of the Republic of Indonesia No. M.02.PR.08.10 of 2004 concerning Procedures for Appointment of Members, Dismissal of Members, Organizational Structure, Procedures and Procedures for Examination of Notary 
Supervisory Boards, Notary Central Supervisory Board is authorized to examine and decide on appeals, with Determination of Notary Central Audit Board No. M.04/MPPN/07.17 of 2017 dated June 19, 2017. After reading the appeal case file No. 04/Reg-Banding/MPPN/VI/2017 dated June 22, 2017, based on Article 35 paragraph (1) Regulation of the Minister of Law and Human Rights No. M.02.PR.08.10 of 2004, it is stated that the Central Audit Board can strengthen, amend, or cancel the decision of the Regional Audit Board and decide for themselves. Based on legal considerations as outlined above, in examining this appeal case, any objections argued by the appellant/reported party or claimant/reporting party are considered to have been considered and become an inseparable part of this decision. After reading the articles in Law No. 2 of 2014 concerning Notary Position as amended by Law No. 30 of 2004 concerning Notary Position and the implementation of the Laws and Regulations, and based on the results of the meeting of the Central Audit Board in examining this case, it judges to:

1. Refuse the appellant/reported party's appeal.

2. Strengthen the decision of the Notary Regional Audit Board of West Sumatra Province No. PTS.02/MPWN/SBR/2016 dated July 21, 2016 to punish reported notaries with written warning sanctions.

It was the decision obtained from the Central Audit Board meeting on Monday July 10, 2017, consisting of the chairman and members. This decision was pronounced in a hearing open to the public on Monday, July 10, 2017 by the Examining Board, consisting of the chairman, members and assisted by the secretary of the Audit Board, who was attended by the appellant (formerly reported party) and claimant (formerly the reporting party) (Decision of the Notary Central Supervisory Board No. 04/B/MPPN/VII/2017). The reported appeal was rejected by the Notary Central Supervisory Board, which later strengthened the decision of the Notary Regional Supervisory Board of West Sumatra Province. As a result, it created an obligation on the reported party to carry out the decision of the Regional Supervisory Board to provide a copy of the deed requested by the reporting party through the Notary Supervisory Board in the reported case. The decision of the Notary Central Supervisory Board was submitted to the Regional Supervisory Board of West Sumatra Province to be submitted to the reported party to provide a copy of the deed requested by the reporting party. The Regional Supervisory Board has submitted 2 (two) times within 14 days of notification to the reporting party as an attempt to implement the decision of the Supervisory Board of West Sumatra Province and the Decision of the Notary Central Supervisory Board, to immediately provide a copy of the deed requested by the reporting party.

Decision of the Regional Supervisory Board in imposing administrative sanctions in the form of written warning was not carried out by the reported party. For the decision, the reported party made an appeal as a form of protection of notary rights. The appeal was submitted through the Regional Supervisory Board which then submitted it to the Notary Central Supervisory Board. On the appeal of the reported party, the Notary Central Supervisory Board then carried out the examination process in accordance with the mechanism stipulated in the Republic of Indonesia Minister of Law and Human Rights Regulation (02/2004), which finally stated to reject the reported appeal and strengthen the decision of the Regional Supervisory Board. This process caused the reported party not to carry out the final decision of the Regional Supervisory Board as stipulated in Article 73 paragraph (3) Law on Notary Position. The Notary Central Supervisory Board did not implement the decision on the temporary dismissal toward the reported notary. In addition, to date, based on information obtained from the Regional Office of Law and Human Rights, the decision of the Regional Supervisory Board to temporarily dismissed the notary was not carried out. It rather involved only the issue of giving written and verbal warnings to submit a copy of the deed to the reporting party in which this had been carried out by the Notary Regional Supervisory Board of West Sumatra Province. 


\section{Conclusion}

The regulation regarding the imposition of sanctions for notaries who violate the laws and regulations has been regulated in Law No. 2 of 2014 for amendment to Law No. 30 of 2004 concerning Notary Position, Decree of the Minister of Law and Human Rights of the Republic of Indonesia Number M.39-PW.07.10 of 2004 concerning the Guidelines for Implementing the Tasks of the Notary Supervisory Board, and the Regulation of the Minister of Law and Human Rights of the Republic of Indonesia Number M.02.PR.08.10 of 2004 concerning Procedures for Appointment of Members, Dismissal of Members, Organizational Structure, and Procedures Examination of the Notary Supervisory Board. The legal consequence for the notary, with the decision of the Supervisory Board, was that the reported notary had been given an administrative sanction in the form of a written warning to submit a copy of the deed to the reporting party and a 3 (three) month temporary dismissal to the Notary Central Supervisory Board. The implementation of the Central Supervisory Board's decision regarding the violations committed by the notary was that the Central Supervisory Board examined and tried the reported notary in which they finally rejected the appellant/reported party's appeal and strengthened the Decision of the Notary Regional Audit Board of West Sumatra Province No. PTS.02/MPWN/SBR/2016 dated July 21, 2016 which decided to impose the reported notary with written warning sanctions.

\section{References}

Book

Adjie,H.(2017).Memahami Majelis Pengawas Notaris (MPN) dan Majelis Kehormatan Notaris (MKN). PT. Refika Aditama, Bandung.

Darus, M. L. H. (2017). Hukum Notariat dan Tanggungjawab Jabatan Notaris.

Kanter, E.Y. (2001). Etika Profesi Hukum: Sebuah Pendekatan Religius. Jakarta: Storia Grafika.

Sjaifurrachman, (2011). Aspek Pertanggungjawaban Notaris dalam Pembuatan Akta, Bandung: Mandar Maju.

Soekanto, S. (1986). Pengantar Ilmu Hukum, Jakarta: UII Press.

\section{Journals}

Buchanan, J., Chai, D. H., \& Deakin, S. (2014). Empirical analysis of legal institutions and institutional change: multiple-methods approaches and their application to corporate governance research. Journal of Institutional Economics, 10(1), 1-20.

Purwaningsih, E. (2015). Bentuk Pelanggaran Hukum Notaris di Wilayah Provinsi Banten dan Penegakan Hukumnya. Mimbar Hukum-Fakultas Hukum Universitas Gadjah Mada, 27(1), 14-28.

Webley, L. (2010). Qualitative approaches to empirical legal research. The Oxford handbook of empirical legal research, 926-950.

\section{Legislation}

Law No. 2 of 2014 concerning Amendment to Law No. 30 of 2004 concerning Notary Position. 
Regulation of the Minister of Law and Human Rights of the Republic of Indonesia Number 2 of 2004 concerning Procedures for Appointment of Members, Organizational Structure, and Procedures for Examination of Notary Supervisory Board.

Decree of the Minister of Law and Human Rights of the Republic of Indonesia No. M.39.PW.07.10 of 2004 concerning Guidelines for the Implementation of Tasks of the Notary Supervisory Board.

Decision of the Regional Supervisory Board No. Pts.02/MPWA/SBR/2016.

Decision of the Notary Central Supervisory Board No. 04/B/MPPN/VII/2017.

\section{Copyrights}

Copyright for this article is retained by the author(s), with first publication rights granted to the journal. This is an open-access article distributed under the terms and conditions of the Creative Commons Attribution license (http://creativecommons.org/licenses/by/4.0/). 